\title{
Studi Perbandingan Kekuatan Lentur Balok Prategang di Daerah Risiko Gempa Berdasarkan SNI 03-2847-2002, SNI 2847:2013, dan ACI 318M-14 pada Struktur Apartamen Enviro Bekasi
}

\author{
Hemas Mutia Anggraini, Tavio, dan , I Gusti Putu Raka \\ Departeman Teknik Sipil, Fakultas Teknik Sipil Lingkungan Dan Kebumian, \\ Institut Teknologi Sepuluh Nopember \\ e-mail: tavio@ce.its.ac.id
}

\begin{abstract}
Abstrak-Suatu teknologi konstruksi dengan mengkombinasi antara beton mutu tinggi dengan baja mutu tinggi dengan cara menarik baja dan menahannya pada beton, sehingga membuat beton dalam keadaan tertekan yang disebut dengan beton prategang. Keuntungan beton prategang dibandingkan beton bertulang yaitu penggunaan dimensi penampang struktur prategang akan lebih kecil atau langsing, sebab seluruh luas penampang dipergunakan secara efektif. Dikarenakan kebutuhan akan ruang yang luas pada gedung Apartemen Enviro dimana digunakan sebagai ruang pertemuan maupun pesta maka pada lantai 12a dibangun multifunction hall. Atas dasar kebutuhan ruangan yang luas tanpa kolom sehingga membutuhkan balok yang panjang maka elemen struktur beton bertulang diganti menggunakan beton prategang.

Berdasarkan identifikasi tanah dari hasil uji Standart Penetration Test (SPT) dan Peta Hazard 2017, diketahui bahwa Kota Bekasi merupakan wilayah dengan jenis tanah sedang yaitu KDS D, maka struktur bangunan direncanakan dengan metode Sistem Rangka Pemikul Momen Khusus (SRPMK), sedangkan untuk desain struktur mengacu pada SNI 2847:2013.

Dalam studi ini penulis juga membandingkan penggunaan tiga jenis peraturan yaitu SNI 2847-2002, SNI 2847:2013 dan ACI 318M-14 yang akan digunakan untuk merencanakan gedung Apartemen Enviro pada balok prategang dengan tinjauan kekuatan lentur. Studi ini dilakukan untuk mendapatkan perturan mana yang paling efisien dan memenuhi segala persyaratan keamanan, sehingga nantinya perencanaan dapat dilaksanakan dengan tepat.
\end{abstract}

Kata Kunci- Beton Prategang, SRPMK, SNI 03-2847-2002, SNI 2847:2013, ACI 318M-14, Apartemen Enviro.

\section{PENDAHULUAN}

$\mathrm{P}$ ESATNYA parkembangan dalam bidang teknik sipil, memunculkan suatu teknologi konstruksi dengan mengkombinasi antara beton mutu tinggi dengan baja mutu tinggi dengan cara menarik baja dan menahannya pada beton yang disebut dengan beton prategang. Dengan memanfaatkan kombinasi aktif pada beton dan baja dimana kemampuan beton dalam menahan tarikan diperbaiki dengan memberikan tekanan, sementara kemampuannya menahan tekanan tidak dikurangi. Sehingga, beton prategang merupakan kombinasi yang ideal dari dua buah bahan modern yang berkekuatan tinggi [1].

Gedung Apartemen Enviro merupakan gedung apartemen simetris dimana memiliki 14 lantai termasuk atap. Karena kebutuhan akan ruang yang luas pada gedung Apartemen Enviro dimana digunakan sebagai ruang pertemuan maupun pesta maka pada lantai 12a dibangun multifunction hall. Atas dasar kebutuhan ruangan yang luas tanpa kolom sehingga panjang balok sangat jauh maka elemen struktur beton bertulang diganti menggunakan beton prategang.

Di dalam studi ini, menitikberatkan pada persamaan kekuatan lentur balok beton prategang dimana balok berfungsi sebagain elemen struktur yang memegang peran sebagai pemikul beban, terutama beban lentur. Beban lentur tersebut dipengaruhi oleh daerah gempa pada bangunan tersebut dibangun. Sehingga diperlukan analisa antara persyaratan keamanan dari kekuataan lentur terhadap daerah gempa gedung Apartemen Enviro menggunakan balok beton prategang.

Dalam studi ini penulis menggunakan pedoman SNI 032847-2002, SNI 2847:2013 tentang Tata Cara Perhitungan Beton untuk Bangunan Gedung, ACI 318M-14 tentang Metric Building Code Requirements for Structural Concrete and Commentary, SNI 1727-2013 tentang Peraturan Pembebanan Indonesia untuk Gedung dan Bangunan Lain, PPIUG 1983 tentang Peraturan Pembebanan Gedung serta peraturan mengenai beton prategang yang memenuhi syarat tahan gempa.

\section{METODE STUDI}

Perencanaan struktur gedung tahan gempa di Indonesia sangat penting mengingat sebagian besar wilayahnya berada dalam area cincin api, yang memiliki intensitas gempa rendah hingga tinggi. Salah satu syarat penting struktur tahan gempa adalah daktilitas yang memadai. Sebuah struktur memiliki daktilitas yang baik bila elemen-elemen struktur penyusunnya juga memiliki daktilitas yang baik. Konstruksi dengan beton bertulang merupakan jenis konstruksi yang paling banyak digunakan karena mudah dalam mendapatkan material dan pelaksanaannya. Beton bertulang efektif digunakan pada 
konstruksi dengan bentang balok yang tidak terlalu panjang sedangkan untuk konstruksi balok dengan bentang yang panjang digunakan beton prategang dengan dimensi yang relatif kecil.

Penggunaan beton bertulang tidak efisien karena ukuran balok menjadi sangat besar sehingga tidak sesuai dengan segi estetika dan arsitektural. Selain itu, beban sendiri dari beton bertulang menjadi dominan dan beban gempa juga akan meningkat. Salah satu solusi yang bisa digunakan yaitu dengan menggunakan sistem beton prategang.

\section{A. Sistem Rangka Pemikul Momen (SRPM)}

Menurut SNI 1726:2012 pasal 3.53 sistem rangka pemikul momen merupakan sistem struktur yang pada dasarnya memiliki rangka ruang yang berfungsi untuk memikul beban gravitasi secara lengkap, ditunjukkan pada Gambar 1[2]. SRPM ini dibagi menjadi tiga jenis, yaitu: Sistem Rangka Pemikul Momen Biasa (SRPMB), Sistem Rangka Pemikul Momen Menengah (SRPMM), dan Sistem Rangka Pemikul Momen Khusus (SRPMK)

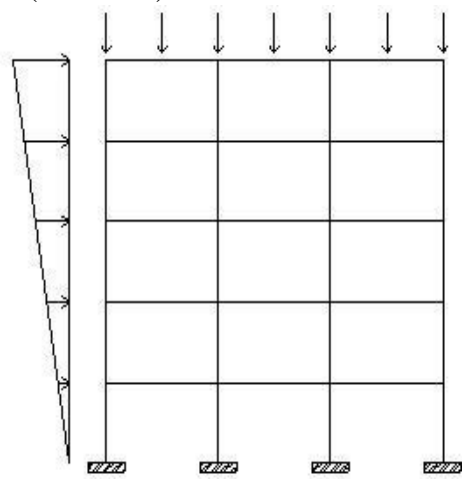

Gambar 1. Sistem rangka pemikul momen.

Berdasarkan SNI 2847:2013, perencanaan pembangunan gedung bertingkat untuk daerah dengan resiko gempa tinggi mengunakan Sistem Rangka Pemikul Momen Khusus (SRPMK)[3]. Struktur beton bertulang yang berada pada wilayah gempa dan resiko gempa kuat (kerusakan merupakan resiko utama), maka komponen struktur harus memenuhi syarat perencanaan dan pendetailan dari SNI 2847:2013 pasal 21.5.

\section{B. Sistem Beton Pratekan}

Pada dasarnya beton prategang diklasifikasikan menjadi dua jenis,yaitu :

\section{1) Pre-tensioned Prestressed Concrete (Pratarik)}

Pratarik adalah metode prategang dimana tendon ditegangkan sebelum beton di cor. Setelah beton cukup keras tendon dipotong dan gaya prategang akan tersalur ke beton melalui lekatan.untuk metode pratarik ini terdapat kekurangan pada peletakan posisi tendon, tendon hanya biasa dipasang dengan bentuk horizontal saja.

Setelah gaya prategang ditransfer ke beton, balok beton akan melengkung ke atas sebelum menerima beban kerja. Setelah beban kerja bekerja, maka balok beton tersebut akan rata.

2) Post-Tensioned Prestressed Concrete (Pascatarik)

Pascatarik adalah metode prategang dimana tendon ditarik setelah beton di cor. Sebelum pengecoran, dipasang dahulu selongsong untuk alur tendon. Setelah beton mengeras tendon dimasukan ke dalam selubung tendon yang sudah dipasang.
Penarikan dilakukan setelah beton mencapai kekuatan yang diinginkan. Setelah penarikan dilakukan proses grooting.

\section{METODOLOGI}

\section{A. Umum}

Langkah-langkah pengerjaan tugas akhir ini dilakukan seperti Gambar 2 berikut:
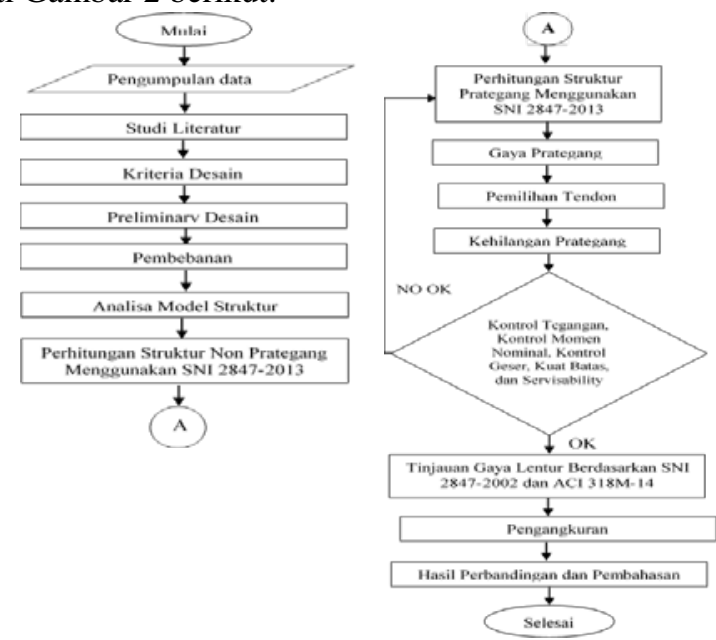

Gambar 2. Diagram alir.

\section{B. Data Bangunan}

Model bangunan seperti pada Gambar 3 dan data bangunan adalah sebagai berikut :

1) Nama proyek : Proyek Apartemen Enviro, Bekasi

2) Jumlah lantai : :14 lantai

3) Tinggi Bangunan : $49,8 \mathrm{~m}$

4) Lantai $1 \quad: 5 \mathrm{~m}$

5) Lantai 2-12 : :3,2 m

6) Lantai 12a $: 5 \mathrm{~m}$

7) Lantai RT : $2,3 \mathrm{~m}$

8) Jenis Tanah : : Tanah Sedang (SD)

9) Struktur Bangunan Atas: Konstruksi beton bertulang

10) Struktur Atap: Pelat beton betulang dengan balok prategang

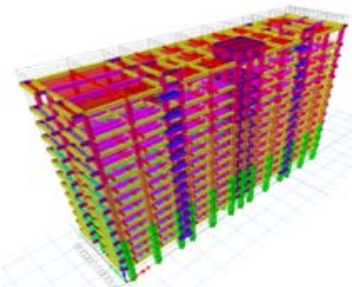

Gambar 3. Model apartemen Enviro-Bekasi.

\section{KONTROL HASIL ANALISA STRUKTUR}

\section{A. Kontrol Periode}

Periode struktur fundamental, $T$, dalam arah yang ditinjau harus diperoleh menggunakan properti struktur dan karakteristik deformasi elemen penahan dalam analisis yang teruji. Periode fundamental, T, tidak boleh melebihi hasil koefisien untuk batasan atas pada periode yang dihitung $(\mathrm{Cu})$ dan periode fundamental pendekatan, Ta.

Dari Gambar diatas didapatkan nilai $\mathrm{T}=1,42$ 


$$
\begin{gathered}
T=C u \times T a \\
T=1,4 \times 1,505=2,106 s
\end{gathered}
$$

Maka 1,42 <2,106 (memenuhi)

\section{B. Kontrol Nilai Akhir Respon Spektrum}

Nilai akhir $\mathrm{V}_{\text {dinamik }}$ harus lebih besar sama dengan $85 \% \mathrm{~V}$ statik Maka persyaratan tersebut dapat dinyatakan sebagai berikut:

Gempa Arah X

$$
\text { Vdinamik } \geq \text { Vstatik }
$$

$$
\begin{array}{r}
\text { Gempa Arah } Y \\
\mathrm{~V}_{\text {dinamik }} \geq 85 \% \mathrm{~V}_{\text {statik }} \\
397914,19 \mathrm{~kg} \geq 85 \% 440328,38 \mathrm{~kg} \\
397914,19 \mathrm{~kg} \geq 374279,12 \mathrm{~kg}(\mathrm{OK})
\end{array}
$$

\section{Kontrol Nilai Partisipasi Massa}

Berdasarkan SNI 1726:2012 Ps. 7.9.1 bahwa analisis harus menyertakan jumlah ragam yang cukup untuk mendapatkan partisipasi massa ragam terkombinasi paling sedikit $90 \%$ dari respon total dari perhitungan respon dinamik[2]. Tabel 1 menunjukkan partisipasi massa ragam terkombinasi.

Tabel 1.

Kontrol partisipasi massa

\begin{tabular}{llll}
\hline \multicolumn{3}{l}{ Kontrol partisipasi massa } \\
\hline \hline Case & Mode & Sum UX & Sum UY \\
Modal & 1 & 0,6486 & 0,000013 \\
Modal & 2 & 0,6486 & 0,7406 \\
Modal & 3 & 0,7428 & 0,7406 \\
Modal & 4 & 0,8304 & 0,7406 \\
Modal & 5 & 0,8308 & 0,8551 \\
Modal & 6 & 0,8562 & 0,8579 \\
Modal & 7 & 0,8791 & 0,8579 \\
Modal & 8 & 0,8921 & 0,8586 \\
Modal & 9 & 0,8924 & 0,8944 \\
Modal & 10 & 0,9184 & 0,8944 \\
Modal & 11 & 0,9195 & 0,9267 \\
Modal & 12 & 0,9282 & 0,9307 \\
Modal & 13 & 0,9377 & 0,9307 \\
Modal & 14 & 0,9377 & 0,9435 \\
Modal & 15 & 0,9417 & 0,9436 \\
\hline \hline
\end{tabular}

\section{Kontrol Simpangan}

Berdasarkan SNI 1726:2012 kontrol drift dan syarat drift harus ditentukan berdasarkan perumusan 34 pada SNI 1726:2012 Pasal 7.8.6 pada persamaan (2). Tabel 2 dan Tabel menunjukkan simpangan pada arah $\mathrm{X}$ dan $\mathrm{Y}$.

$$
\delta_{x}=\frac{C d \times \delta x e}{I}
$$

Dimana:

$\delta_{x}=$ Defleksi pada lantai ke-x

$C_{d}=$ Faktor pembesaran defleksi

$I \quad=$ Faktor keutamaan gempa
Tabel 1.

Kontrol simpangan arah X

\begin{tabular}{lllllll}
\hline \hline Story & $\begin{array}{r}\text { Drift } \\
(\mathrm{mm})\end{array}$ & \multicolumn{1}{c}{$\Delta$} & $\Delta . \mathrm{Cd} / \mathrm{Ie}(\mathrm{mm})$ & $\begin{array}{c}\mathrm{h} \\
(\mathrm{m})\end{array}$ & $\begin{array}{c}\Delta \text { izin } \\
(\mathrm{mm})\end{array}$ & Cek \\
\hline RT & 23,14 & $-0,318$ & $-1,749$ & 2,3 & 46 & Oke \\
15TH & 23,458 & 1,163 & 6,396 & 5 & 100 & Oke \\
12.aTH & 22,295 & 0,947 & 5,209 & 3,2 & 64 & Oke \\
12TH & 21,348 & 1,304 & 7,172 & 3,2 & 64 & Oke \\
11TH & 20,044 & 1,651 & 9,081 & 3,2 & 64 & Oke \\
10TH & 18,393 & 1,619 & 8,905 & 3,2 & 64 & Oke \\
9TH & 16,774 & 1,833 & 10,082 & 3,2 & 64 & Oke \\
8TH & 14,941 & 2,047 & 11,259 & 3,2 & 64 & Oke \\
7TH & 12,894 & 2,228 & 12,254 & 3,2 & 64 & Oke \\
6TH & 10,666 & 2,347 & 12,909 & 3,2 & 64 & Oke \\
5TH & 8,319 & 2,231 & 12,271 & 3,2 & 64 & Oke \\
4TH & 6,088 & 2,198 & 12,089 & 3,2 & 64 & Oke \\
3RD & 3,89 & 1,775 & 9,763 & 3,2 & 64 & Oke \\
2ND & 2,115 & 2,115 & 11,633 & 3,2 & 64 & Oke \\
Base & 0 & 0,000 & 0,000 & 5 & 100 & Oke \\
\hline \hline
\end{tabular}

Tabel 2.

Kontrol simpangan arah Y

\begin{tabular}{lllllll}
\hline \hline Story & $\begin{array}{l}\text { Drift } \\
(\mathrm{mm})\end{array}$ & $\Delta$ & $\begin{array}{l}\Delta . \mathrm{Cd} / \mathrm{Ie} \\
(\mathrm{mm})\end{array}$ & $\mathrm{h}(\mathrm{m})$ & $\Delta$ izin $(\mathrm{mm})$ & Cek \\
\hline RT & 23,797 & 0,438 & 2,409 & 2,3 & 46 & Oke \\
15TH & 23,359 & 1,362 & 7,491 & 5 & 100 & Oke \\
12.aTH & 21,997 & 1,045 & 5,747 & 3,2 & 64 & Oke \\
12TH & 20,952 & 1,366 & 7,513 & 3,2 & 64 & Oke \\
11TH & 19,586 & 1,676 & 9,218 & 3,2 & 64 & Oke \\
10TH & 17,91 & 1,639 & 9,015 & 3,2 & 64 & Oke \\
9TH & 16,271 & 1,830 & 10,065 & 3,2 & 64 & Oke \\
8TH & 14,441 & 2,016 & 11,088 & 3,2 & 64 & Oke \\
7TH & 12,425 & 2,171 & 11,941 & 3,2 & 64 & Oke \\
6TH & 10,254 & 2,260 & 12,430 & 3,2 & 64 & Oke \\
5TH & 7,994 & 2,141 & 11,776 & 3,2 & 64 & Oke \\
4TH & 5,853 & 2,106 & 11,583 & 3,2 & 64 & Oke \\
3RD & 3,747 & 1,648 & 9,064 & 3,2 & 64 & Oke \\
2ND & 2,099 & 2,099 & 11,545 & 3,2 & 64 & Oke \\
Base & 0 & 0,000 & 0,000 & 5 & 100 & Oke \\
\hline \hline
\end{tabular}

\section{HASIL PERENCANAAN}

\section{A. Preliminary Design}

Berikut ini hasil dari preliminary design balok, pelat dan kolom:

1) Balok

Hasil preliminary design struktur balok pada Tabel 4 dibawah ini:

\begin{tabular}{lcl}
\multicolumn{3}{c}{$\begin{array}{c}\text { Tabel 4. } \\
\text { Tipe balok }\end{array}$} \\
\hline \hline Tipe Balok & $\mathrm{b}(\mathrm{cm})$ & $\mathrm{h}(\mathrm{cm})$ \\
\hline BI 1 & 45 & 55 \\
BI 2 & 40 & 50 \\
BA 1 & 30 & 45 \\
BA 2 & 25 & 35 \\
\hline \hline
\end{tabular}

2) Balok Pratekan

Balok Pratekan direncanakan menggunakan dimensi 45/65 dengan bentang $12 \mathrm{~m}$. 
3) Pelat

Pelat lantai dan pelat atap direncanakan menggunakan tebal 11 $\mathrm{cm}$.

4) Tangga

Pada pelat bordes dan tangga digunakan tebal $15 \mathrm{~cm}$.

5) Kolom

Direncanakan dengan dimensi pada Tabel 5 dibawah ini :

Tabel 5.

Dimensi kolom

\begin{tabular}{lll}
\hline \hline Tipe Kolom & $\mathrm{b}(\mathrm{cm})$ & $\mathrm{h}(\mathrm{cm})$ \\
\hline K1 & 100 & 100 \\
K2 & 80 & 80 \\
K3 & 60 & 60 \\
\hline \hline
\end{tabular}

B. Desain Struktur SekunderBerikut ini hasil dari desain struktur sekunder pada Tabel 6 :

Tabel 6.

Rekapitulasi hasil struktur sekunder

\begin{tabular}{|c|c|c|}
\hline Element Struktur & $\begin{array}{l}\text { Dimensi } \\
(\mathrm{mm})\end{array}$ & Tulangan \\
\hline Pelat Lantai & $\mathrm{t}=110$ & $\begin{array}{l}\text { D10-200 (Arah X) } \\
\text { D10-200 (Arah Y) } \\
\text { D10-200 (Tul. Susut) }\end{array}$ \\
\hline Pelat Atap & $\mathrm{t}=110$ & $\begin{array}{l}\text { D10-200 (Arah X) } \\
\text { D10-200 (Arah Y) } \\
\text { D10-200 (Tul. Susut) }\end{array}$ \\
\hline Pelat Tangga & $\mathrm{t}=150$ & $\begin{array}{l}\text { D13-150 (Arah X) } \\
\text { D13-250 (Arah Y) } \\
\text { D10-200 (Tul. Susut) }\end{array}$ \\
\hline Balok Bordes & $300 / 450$ & $\begin{array}{l}\text { 4D16 / 2D16 (Tumpuan) } \\
\text { 2D16 / 3D16 (Lapangan) } \\
\text { 2D13 (Tul. Torsi) } \\
\text { 2D13-90 / 2D13-150 ( Sengkang) }\end{array}$ \\
\hline Balok Anak1 (BA1) & $300 / 450$ & $\begin{array}{l}\text { 4D16 / 2D16 (Tumpuan) } \\
\text { 2D16 / 3D16 (Lapangan) } \\
\text { 2D13 (Tul. Torsi) } \\
\text { 2D13-80 / 2D13-150 ( Sengkang) }\end{array}$ \\
\hline Balok Anak2 (BA2) & $250 / 350$ & $\begin{array}{l}\text { 4D16 / 2D16 (Tumpuan) } \\
\text { 2D16 / 3D16 (Lapangan) } \\
\text { 2D13 (Tul. Torsi) } \\
\text { 2D13-70 / 2D13-120 ( Sengkang) }\end{array}$ \\
\hline Balok Lift (BL) & $300 / 450$ & $\begin{array}{l}\text { 4D16 / 2D16 (Tumpuan) } \\
\text { 2D16 / 4D16 (Lapangan) }\end{array}$ \\
\hline
\end{tabular}

Parameter perbandingan kekuatan lentur

\begin{tabular}{|c|c|c|c|c|}
\hline No & Parameter & SNI 03-2847-2002[4] & SNI 2847:2013[3] & ACI 318M-14[5] \\
\hline & & Pasal 23.3.2.1 & Pasal 21.5.2.1 & Ch. 9.6.1.2 \\
\hline 1. & $\begin{array}{l}\text { Tulangan } \\
\text { minimum }\end{array}$ & $\begin{array}{l}\text { As,min }=\frac{0,25 \sqrt{f_{c}^{\prime}}}{f_{y}} b_{w} \cdot d \\
\text { tidak kecil dari } 1,4 \mathrm{bw} \cdot \mathrm{d} / \mathrm{fy}\end{array}$ & $\begin{array}{l}\text { As,min }=\frac{0,25 \sqrt{f_{c}^{\prime}}}{f_{y}} b_{w} \cdot d \\
\text { tidak kecil dari } 1,4 \mathrm{bw} \cdot \mathrm{d} / \mathrm{fy}\end{array}$ & $\begin{array}{l}\text { As,min }=\frac{0,25 \sqrt{f_{c}^{\prime}}}{f_{y}} b_{w} \cdot d \\
\text { tidak kecil dari } 1,4 \mathrm{bw} \cdot \mathrm{d} / \mathrm{fy}\end{array}$ \\
\hline 2. & $\rho \max$ & $\begin{array}{l}\text { Pasal 23.3.2.1 } \\
0,025\end{array}$ & $\begin{array}{l}\text { Pasal 21.5.2.1 } \\
0,025\end{array}$ & $\begin{array}{l}\text { Ch. } 18.6 .3 .1 \\
0,025\end{array}$ \\
\hline 3. & $\begin{array}{l}\text { Minimum Jumlah } \\
\text { Tulangan }\end{array}$ & $\begin{array}{l}\text { Pasal 23.3.2.1 } \\
2 \text { batang tulangan pada kedua sisi } \\
\text { atas dan bawah }\end{array}$ & $\begin{array}{l}\text { Pasal } 21.5 .2 .1 \\
2 \text { batang tulangan pada kedua sisi } \\
\text { atas dan bawah }\end{array}$ & $\begin{array}{l}\text { Ch. } 18.6 .3 .1 \\
2 \text { batang tulangan pada kedua sisi } \\
\text { atas dan bawah }\end{array}$ \\
\hline & & Pasal 23.3.2.2 & Pasal 21.5.2.2 & Ch. 18.6 .3 .2 \\
\hline & & Tumpuan = & Tumpuan= & Tumpuan = \\
\hline 4. & SRPMK & $\begin{array}{l}\mathrm{M}(+) \geq 1 / 2 \mathrm{M}(-) \\
\text { Lapangan= }\end{array}$ & $\begin{array}{l}\mathrm{M}(+) \geq 1 / 2 \mathrm{M}(-) \\
\text { Lapangan= }\end{array}$ & $\begin{array}{l}\mathrm{M}(+) \geq 1 / 2 \mathrm{M}(-) \\
\text { Lapangan= }\end{array}$ \\
\hline & & $M(+/-) \geq 1 / 4$ Mmaks & $\mathrm{M}(+/-) \geq 1 / 4 \mathrm{Mmaks}$ & $\mathrm{M}(+/-) \geq 1 / 4 \mathrm{Mmaks}$ \\
\hline & Kekuatan Desain & $\begin{array}{l}\text { Pasal 11.3.2.1 } \\
0,80\end{array}$ & $\begin{array}{l}\text { Pasal 9.3.2.1 } \\
0,90\end{array}$ & $\begin{array}{l}\text { Ch. 21.2.1 } \\
0,9\end{array}$ \\
\hline 6 & $\begin{array}{l}\text { Selimut } \\
\text { Prategang }\end{array}$ & $\begin{array}{l}\text { Pasal 9.7.3.1 c) } \\
40 \mathrm{~mm}\end{array}$ & $\begin{array}{l}\text { Pasal 7.7.2 c) } \\
40 \mathrm{~mm}\end{array}$ & $\begin{array}{l}\text { Ch. 20.6.1.3 } \\
40 \mathrm{~mm}\end{array}$ \\
\hline 7 & $\beta_{1}$ & $\begin{array}{l}\text { Pasal 12.2.7.3 } \\
\beta_{1}=0,85-0,05 \frac{\left(f^{\prime} c_{c}-30\right)}{7}\end{array}$ & $\begin{array}{l}\text { Pasal 10.2.7.3 } \\
\beta_{1}=0,85-0,05 \frac{\left(f^{\prime}-28\right)}{7}\end{array}$ & $\begin{array}{l}\text { Ch. 22.2.2.4.3 } \\
\beta_{1}=0,85-0,05 \frac{\left(f^{\prime} c^{\prime}-28\right)}{7}\end{array}$ \\
\hline 8 & fps (unbonded) & $\begin{array}{l}\text { Pasal 20.7.2 } \\
\text { Untuk } \ln / \mathrm{h} \leq 35\end{array}$ & $\begin{array}{l}\text { Pasal 18.7.2. a) } \\
\text { Untuk } \ln / \mathrm{h} \leq 35\end{array}$ & $\begin{array}{l}\text { Ch. 20.3.2.4 } \\
\text { Untuk } \ln / \mathrm{h} \leq 35\end{array}$ \\
\hline
\end{tabular}

2D16 (Tul. Torsi)

2D10-60 / 2D10-150 ( Sengkang)

\section{Desain Struktur Primer}

Berikut ini hasil dari desain struktur sekunder Tabel 7:

Tabel 7.

Rekapitulasi Hasil Struktur Primer

\begin{tabular}{lll}
\hline \hline Element Struktur & Dimensi (mm) & Tulangan \\
\hline & & 6D19 / 3D19 (Tumpuan) \\
Balok Induk 1 (BI1) & $450 / 550$ & 2D19 / 4D19 (Lapangan) \\
& & 2D19 (Tul. Torsi) \\
& & 2D13-60/2D13-125 ( Sengkang) \\
& & 4D19 / 2D19 (Tumpuan) \\
Balok Induk 2 (BI2) & \multirow{2}{*}{ 250/350 } & 2D19 / 4D19 (Lapangan) \\
& & 2D19 (Tul. Torsi) \\
& & 2D13-50/2D13-125 ( Sengkang) \\
Kolom 1(K1) & \multirow{2}{*}{ 2000/1000 } & 4D16-100/4D16-100(Sengkang) \\
& & 20D22 (Tul. Lentur) \\
Kolom 2 (K2) & \multirow{2}{*}{$800 / 800$} & 4D16-100/4D16-120(Sengkang) \\
& & 16D19 (Tul. Lentur) \\
Kolom 3 (K3) & $600 / 600$ & 4D14-100/4D14-100(Sengkang) \\
&
\end{tabular}

D. Desain Struktur Prategang

Dimensi balok $=450 / 650$

Panjang balok $=12000 \mathrm{~mm}$

Mutu beton $=40 \mathrm{MPa}$

Mutu tendon =

1) Digunakan strand 7 wire uncoated ASTM A416untuk post tensioning.

2) Nominal diameter $\quad=12,7 \mathrm{~mm}$

3) Luas nominal area kawat $\quad=100,1 \mathrm{~mm}^{2}$

4) Minimum breaking load $\quad=184 \mathrm{kN}$

5) $\mathrm{PPR}=17 \%<25 \%$ (memenuhi)

\section{E. Studi Perbandingan}

Pada studi ini, penulis membandingkan kekuatan lentur pada balok beton prategang berdasarkan SNI 2847-2002, SNI 2847:2013, dan ACI 318M-14. Pada Tabel 8 menunjukkan perbandingan rumus yang akan digunakan.
Tabel 8. 


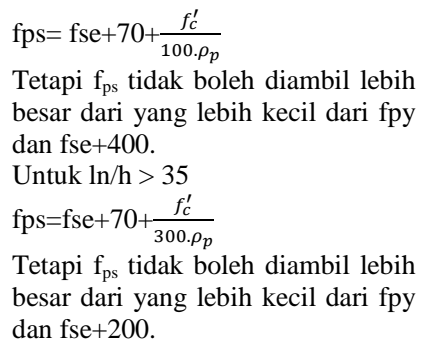

Tetapi $\mathrm{f}_{\mathrm{ps}}$ tidak boleh diambil lebih besar dari yang lebih kecil dari fpy dan fse +400

Untuk $\ln / \mathrm{h}>35$

fps $=$ fse $+70+\frac{f_{c}^{\prime}}{300 \cdot \rho_{p}}$

Tetapi $\mathrm{f}_{\mathrm{ps}}$ tidak boleh diambil lebih besar dari yang lebih kecil dari fpy dan fse+200.

$\mathrm{fps}=\mathrm{fse}+70+\frac{f_{c}^{\prime}}{100 . \rho_{p}}$

Tetapi $\mathrm{f}_{\mathrm{ps}}$ tidak boleh diambil lebih besar dari yang lebih kecil dari fpy dan fse+420.

Untuk $\ln / \mathrm{h}>35$ fps $=$ fse $+70+\frac{f_{c}^{\prime}}{300 \cdot \rho_{p}}$

Tetapi $\mathrm{f}_{\mathrm{ps}}$ tidak boleh diambil lebih besar dari yang lebih kecil dari fpy dan fse+210.

Pasal 21.5.2.5 b)

Baja prategang tidak boleh menyumbang lebih dari seperempat kekuatan lentur positif atau negatif di penampang kritis pada daerah sendi plastis dan harus diangkur atau melewati muka eksterior joint. $\mathrm{fps}=\mathrm{fse}+70+\frac{f_{c}^{\prime}}{100 \cdot \rho_{p}}$

Tetapi $f_{p s}$ tidak boleh diambil lebih besar dari yang lebih kecil dari fpy dan fse+420.

Untuk $\ln / \mathrm{h}>35$

$\mathrm{fps}=\mathrm{fse}+70+\frac{f_{c}^{\prime}}{300 \cdot \rho_{p}}$

Tetapi $f_{p s}$ tidak boleh diambil lebih besar dari yang lebih kecil dari fpy dan fse+210.

Ch. 18.6.3.5

Baja prategang tidak boleh menyumbang lebih dari seperempat kekuatan lentur positif atau negatif di penampang kritis pada daerah sendi plastis dan harus diangkur atau melewati muka eksterior joint.

Hasil dari studi perbandingan kekuatan lentur pada Tabel 9:

Tabel 9.

Hasil Perbandingan Kekuatan Lentur

\begin{tabular}{|c|c|c|c|}
\hline Parameter & SNI 03-2847-2002 & SNI 2847:2013 & ACI 318M-14 \\
\hline \multicolumn{4}{|l|}{ Balok Prategang } \\
\hline Panjang Bentang & $12 \mathrm{~m}$ & $12 \mathrm{~m}$ & 12 \\
\hline Dimensi Balok & $450 \times 650 \mathrm{~mm}$ & $450 \times 650 \mathrm{~mm}$ & $450 \times 650$ \\
\hline Mutu Beton & $40 \mathrm{MPa}$ & $40 \mathrm{MPa}$ & 40 \\
\hline Mutu Baja & $400 \mathrm{MPa}$ & $400 \mathrm{MPa}$ & 400 \\
\hline Jumlah Tendon & 1 buah & 1 buah & 1 \\
\hline Momen Ultimate Tumpuan & 336574264 Nmm & 336574264 Nmm & 336574264 Nmm \\
\hline Momen Ultimate Lapangan & $239557900 \mathrm{Nmm}$ & $239557900 \mathrm{Nmm}$ & $239557900 \mathrm{Nmm}$ \\
\hline Koefisien Reduksi Lentur,Ø & 0,8 & 0,9 & 0,9 \\
\hline \multicolumn{4}{|l|}{ Koefisien Tahanan, Rn } \\
\hline Tumpuan & 2,803 & 2,49 & 2,49 \\
\hline Lapangan & 2 & 1,77 & 1,77 \\
\hline$\rho$ perlu tumpuan & 0,00732 & 0,00648 & 0,00648 \\
\hline$\rho$ perlu lapangan & 0,00514 & 0,00456 & 0,00456 \\
\hline Tulangan Tumpuan Negatif & $5 \mathrm{D} 25$ & $5 \mathrm{D} 25$ & $5 \mathrm{D} 25$ \\
\hline Tulangan Tumpuan Positif & $3 \mathrm{D} 25$ & $3 \mathrm{D} 25$ & $3 \mathrm{D} 25$ \\
\hline Tulangan Lapangan Negatif & $4 \mathrm{D} 25$ & $4 \mathrm{D} 25$ & $4 \mathrm{D} 25$ \\
\hline Tulangan Lapangan Positif & $2 \mathrm{D} 25$ & $2 \mathrm{D} 25$ & $2 \mathrm{D} 25$ \\
\hline Momen Nominal Tumpuan & $420717830 \mathrm{Nmm}$ & 37391404,4 Nmm & 37391404,4 Nmm \\
\hline Momen Nominal Lapangan & 299447374,5Nmm & 266175444 Nmm & 266175444 Nmm \\
\hline Jenis Tendon & Tak Terlekat & Tak Terlekat & Tak Terlekat \\
\hline$\beta_{1}$ & 0,779 & 0,754 & 0,754 \\
\hline Momen Nominal Prategang & 933715377,1 Nmm & $\begin{array}{l}\text { 933715377,1 } \\
\text { Nmm }\end{array}$ & 933715377,1 Nmm \\
\hline Momen Nominal Total & 1281262873 Nmm & $1281262873 \mathrm{Nmm}$ & $1281262873 \mathrm{Nmm}$ \\
\hline PPR & $17 \%$ & $17 \%$ & $17 \%$ \\
\hline
\end{tabular}

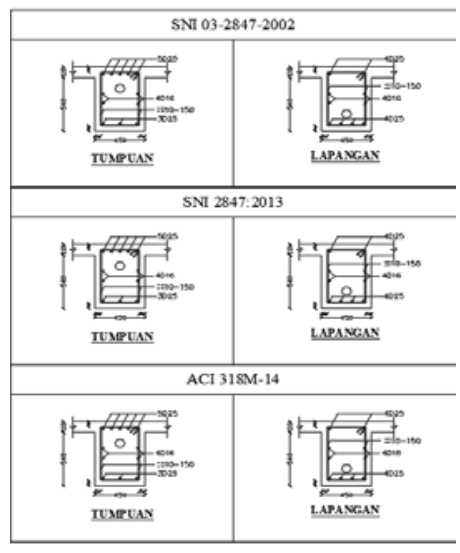

Gambar 4. Perbandingan penulangan balok prategang.

Dari hasil perbandingan pada Gambar 5 didapatkan hasil yang sama antara SNI 2847:2013 dengan ACI 318M-14, sedangkan SNI 03-2847-2002 dengan SNI 2847:2013 memiliki perbedaan yang tidak signifikan sehingga didpatkan jumlah dan ukuran tulangan lentur yang sama. Hal ini dikarenakan perbedaan antara SNI 03-2847-2002 dengan SNI 2847:2013 hanya terdapat pada koefisien rumus, sehingga tidak memberikan dampak yang besar pada jumlah dan ukuran tulangan lentur yang ada.

\section{PENUTUP}

\section{A. Kesimpulan}

Bangunan Gedung Apartemen Enviro termasuk dalam KDS D sehingga prencanaan bangunan ini menggunakan SRPMK. Penggunaan beton prategang pada bangunan ini mencapai rasio $17 \%$ dengan batas maksimal 25\% sehingga telah memenuhi syarat ketentuan yang ada.

Hasil tulangan lentur pada balok prategang yang didapatkan dari tiga perturan tersebut menghasilkan tidak signifikan, sehingga untuk struktu-struktur gedung lain yang sudah didesau berdasarkan SNI 03-2847-2002, SNI 2847:2013, maupun ACI 318M-14 tidka memneui masalah dalam kebutuhan tulangan lentur yang sudah terpasang pada struktur. Jika ditinjau kekuatan lentur untuk balok prategang perbedaan 
terdapat pada nilai koefisien $\emptyset$, dimana nilai $\emptyset$ pada SNI 032847-2002 lebih kecil dibandingkan pada SNI 2847:2013, maupun ACI 318M-14, sehingga mempengaruhi nilai momen nominal dan kebutuhan tulangan lebih banyak.

\section{B. Saran}

Diperlukan adanya studi lanjutan terhadap beton prategang kondisi terlekat dan dimensi beton pratekan yang paling efisien hingga mendapatkan tulangan lunak berdasarkan SNI 03-28472002, SNI 2847:2013 san ACI 318M-14.

Diperlukan adanya studi lanjutan berupa biaya material yang dibutuhkan untuk tulangan lentur.

\section{DAFTAR PUSTAKA}

[1] T. Y. Lin and T. Y. Lin, "Desain Struktur Beton Prategang. Jilid 1," 1. Bet. PRATEGANG,Desain Strukt. Bet. prategang. Jilid 1 / oleh T.Y. Lin, Ned H. Burn. Penerjemah Daniel Indrawan, vol. 1993, no. 1993, pp. 199, 1993.

[2] B. S. Nasional, "Tata Cara Perencanaan Ketahanan Gempa untuk Struktur Bangunan Gedung dan Non-Gedung,” 2012.

[3] Badan Standardisasi Nasional, "Persyaratan Beton Struktural untuk Bangunan Gedung,” 2013.

[4] T. Cara, P. Struktur, B. Untuk, and B. Gedung, "Tata Cara Perhitungan Struktur Beton untuk Bangunan Gedung.”

[5] "Building Code Requirements for Structural Concrete (ACI 318-14) Commentary on Building Code Requirements for Structural Concrete (ACI 318R-14) An ACI Standard and Report,” 2014. 